\title{
36. HIGH-RESOLUTION SILICA PORE-WATER PROFILES IN SEDIMENTS OF THE MADEIRA ABYSSAL PLAIN, EASTERN NORTH ATLANTIC ${ }^{1}$
}

\author{
Gert J. De Lange ${ }^{2}$
}

\begin{abstract}
High-resolution pore-water sampling has been undertaken to define the pore-water silica profile vs. depth for Holes 950A and 952A in the Madeira Abyssal Plain, eastern North Atlantic. The silica pore-water concentration in the upper 50 meters below seafloor (mbsf) faithfully records the presence of biogenic silica in organic-rich turbidites. Between 50 and 250 mbsf, that is, between 1 and $6.5 \mathrm{Ma}$, however, the silica pore-water concentration is low and stable, pointing to the absence of biogenic silica in the organic-rich turbidites in this interval. Such absence could indicate a change in source area, or in the northwest African upwelling system during that period.

Near $280 \mathrm{mbsf}$ in Hole 950A, and below $290 \mathrm{mbsf}$ in Hole 952A, enhanced levels of silica are again observed in the pore waters, which indicates that biogenic silica is present in the deep organic-rich turbidites. For Hole 952A, this coincides with the interval where enhanced levels of diatoms have been reported. The high-resolution pore-water sampling in Holes $950 \mathrm{~A}$ and 952A has resulted in the identification of potential intervals where authigenic silica phases are likely to have formed, thus enabling future studies on the diagenetic redistribution of silica in marine sediments.
\end{abstract}

\section{INTRODUCTION}

Silica concentrations in marine pore waters vary between 100 and $1000 \mu \mathrm{m}$, but usually fall between 100 and $400 \mu \mathrm{m}$ at normal seawater temperatures (e.g., Schink et al., 1974; Jahnke et al., 1982; De Lange, 1986). Even in sediments that contain some biogenic opal (radiolarians, diatoms, etc.), the pore-water concentration of silica is mostly far below its solubility-product-controlled concentration of $1000 \mu \mathrm{m}$ (Hurd, 1973). Consequently, the thermodynamic-controlled dissolution of biogenic opal must be accompanied by the kineticcontrolled incorporation of silica into a less soluble authigenic solid phase. Minerals such as smectite, chamosite, and nontronite are among the phases that have been reported to result from such redistribution of silica (e.g., Harder, 1978; Hein et al., 1979; Maris and Bender, 1982; De Lange and Rispens, 1986).

Some late-Quaternary organic-rich turbidites in the Madeira Abyssal Plain have been reported to contain a small percentage of biogenic opal (Kuijpers, 1982). Corresponding distinct maxima in the silica pore-water profiles occur at the depth levels of such turbidites, whereas distinct minima occur at intervals that have a higher proportion of pelagic intervals (e.g., De Lange et al., 1992). The concentration gradients found by De Lange et al. (1992) over the top 35 $\mathrm{m}$ of the sediments from the Madeira Abyssal Plain could only have resulted in the accumulation of, at most, $0.1 \%$ authigenic phases in distinct intervals. If fluxes of a similar magnitude lasted not for 0.5 $\mathrm{Ma}$, but rather from 5 to $10 \mathrm{Ma}$, then substantial and more easily detectable amounts could have accumulated. The recovery of older turbiditic units during Leg 157 offered the opportunity to test this hypothesis. For this purpose, pore waters have been sampled at high resolution throughout Holes 950A and 952A. The aim of this study was to detect silica pore-water gradients to identify promising intervals for future sediment sampling of authigenic silica phases.

${ }^{1}$ Weaver, P.P.E., Schmincke, H.-U., Firth, J.V., and Duffield, W. (Eds.), 1998. Proc. ODP Sci. Results, 157: College Station, TX (Ocean Drilling Program).

${ }^{2}$ Utrecht University, Institute of Earth Sciences, Department of Geochemistry, Budapestlaan 4, 3584 CD Utrecht, The Netherlands. gdelange@earth.ruu.nl

\section{METHODS}

After the pore-water extraction by hydraulic squeezing aboard ship, the samples were stored under cool conditions until their analysis 2 weeks after the cruise. Dissolved silica concentrations were measured using a Technicon TRAACS AutoAnalyzer; standards were made in "aged" seawater low in dissolved silica. Each sample was analyzed at least in duplicate in different analytical runs. Analytical errors determined on replicate analyses of a few samples are better than $3 \%$.

\section{RESULTS AND DISCUSSION}

Leg 157 recovered a large number of organic-rich turbidites from 0 to $15-20 \mathrm{Ma}$ (Howe and Sblendorio-Levy, Chap. 29, this volume), that were deposited at least as abundantly as in the intervals of 0-35 meters below seafloor (mbsf) reported earlier (e.g., Schminke, Weaver, Firth, et al., 1995; De Lange et al., 1987; Weaver and Rothwell, 1987; Weaver et al., 1992; Rothwell et al., Chap. 28, this volume).

The silica pore-water data of previous investigations in the Madeira Abyssal Plain demonstrated smooth profiles with very clear maxima and minima in sediments down to 35 mbsf (e.g., De Lange et al., 1992). In the present study, however, there appears to be consistently low values below a depth of $\sim 50-250 \mathrm{mbsf}$ (Fig. 1; Tables $1,2)$. It should be noted that the pore-water concentration of silica is sensitive to the temperature of squeezing. If the temperature of squeezing deviates $20^{\circ} \mathrm{C}$ from the in situ temperature, then deviations of $10 \%-60 \%$ in the silica pore-water concentration have been reported to occur (e.g., Fanning and Pilson, 1971; Mangelsdorf et al., 1969; Sayles et al., 1973, 1976; De Lange et al., 1992). This temperature effect seems to be dependent on the type of sediment involved. Clays and marly sediment are reported to be more sensitive than siliceous oozes, consequently, to give larger deviations from the in situ porewater concentration. Ocean Drilling Program (ODP) samples cannot be adequately squeezed under temperature-controlled conditions aboard the JOIDES Resolution, which most of the time is unnecessary in view of the temperature gradients found in the sediments usually recovered by ODP. All silica pore-water concentrations in this study are, therefore, likely to be somewhat higher than the in situ con-

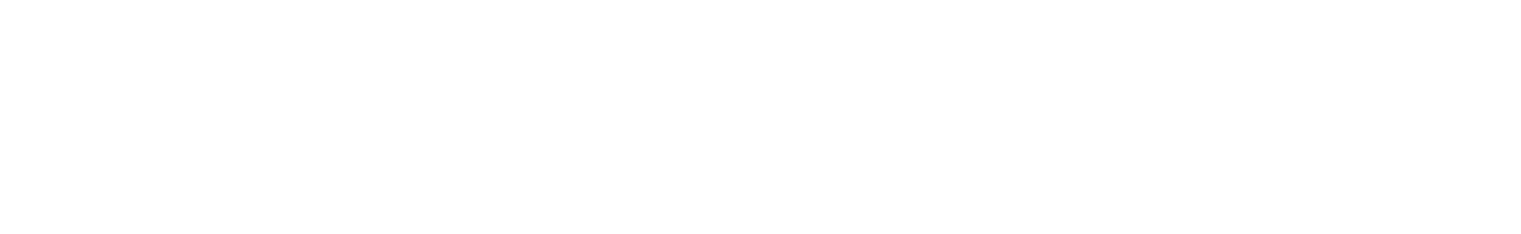



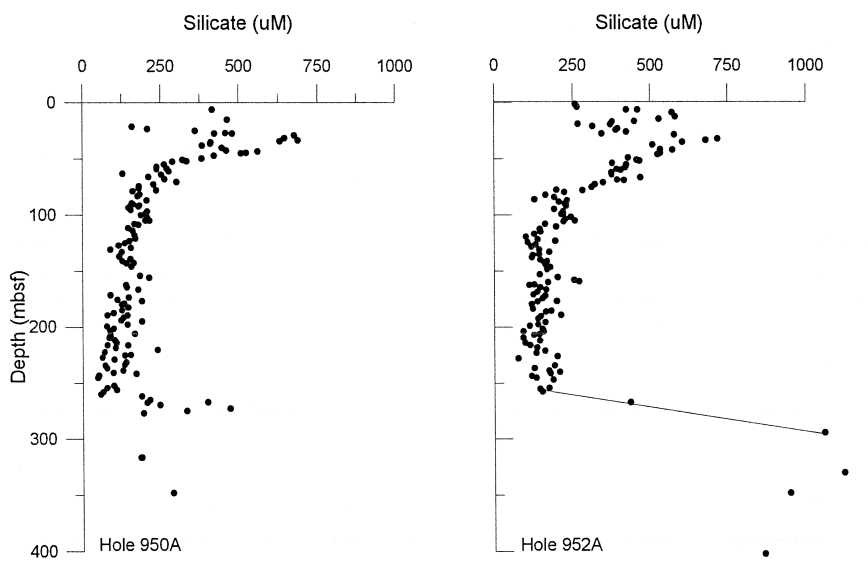

Figure 1. Silica pore-water concentration vs. depth for the interval of 0-400 mbsf in Holes 950A and 952A.

centrations. In addition, most of the small variations in the concentration of silica, such as observed between 50 and $250 \mathrm{mbsf}$, may be attributable to such temperature of squeezing artifacts. In summary, the temperature of squeezing may have caused minor changes in the silica pore-water profiles. The main picture of the profiles, however, is considered to be largely unaffected by such artifacts.

The silica pore-water concentration in the intervals between 50 and $250 \mathrm{mbsf}$ appears to be rather low and relatively stable, with only a minor decrease with depth (Fig. 1). The occurrence of organic-rich turbidites containing some biogenic silica coincides with enhanced levels of pore-water silica in the sediments of the upper $50 \mathrm{mbsf}$ (Fig. 2; compared to Schmincke, Weaver, Firth, et al., 1995). It seems, therefore, that no (biogenic) opal occurs in the interval of 50-250 mbsf, despite the repetitive occurrence of organic-rich turbidites (see Schminke, Weaver, Firth, et al., 1995). It is only below $290 \mathrm{mbsf}$ in Hole 952A, and 280 mbsf in Hole 950A, that enhanced levels of silica occur again in the pore waters. The rare occurrence of biogenic silica is reported for the interval below $100 \mathrm{mbsf}$ in Hole 950A, and a rapidly increasing $\mathrm{Si} / \mathrm{Al}$ ratio in unit $\mathrm{I} / 4$ from 270 to $295 \mathrm{mbsf}$ (Jarvis et al., Chap. 31, this volume). The amount of diatoms in Hole 952A is reported to increase again below $290 \mathrm{mbsf}$, coinciding with the rapid increase in silica pore-water concentration vs. depth (Schminke, Weaver, Firth, et al., 1995).

There are two alternative explanations for the absence of biogenic silica in organic-rich turbidites deposited approximately between 1 and $10 \mathrm{Ma}$ (Howe and Sblendorio-Levy, Chap. 29, this volume): (1) only minor amounts of biogenic silica were initially present and have been dissolved since deposition (about $<1 \%$ ), or (2) the organic-rich turbidites did not contain any biogenic silica at all upon deposition. In any case, such low or absent biogenic opal content may point to a different source area for this group of organic-rich turbidites, or to a change or shift in the northwest African upwelling system.

If studied in more detail, it is clear that the silica pore-water concentration faithfully follows the presence of organic-rich turbidites in which some biogenic silica occurs (e.g., Fig. 2). The silica pore-water gradients and related fluxes in the sediments of the upper part of these holes seems relatively small compared with those in the sediments at 280 and 290 mbsf in Holes 950A and 952A, respectively. However, the silica flux calculated from these profiles is $4 * 10^{-2}$ and $2.5^{*} 10^{-2}$ $\mu \mathrm{m} / \mathrm{cm}^{2}$ per yr, respectively, for the intervals at $\sim 30$ and $290 \mathrm{mbsf}$ in Hole 952A. If fluxes are assumed to have remained the same since briefly after deposition of the opal-containing organic-rich turbidite involved, then the amount of authigenic silica that has formed can be calculated. It appears that the amount formed at $290 \mathrm{mbsf}$ is $10 \times$ larger than that formed at $30 \mathrm{mbsf}$ in Hole 952A. Consequently, the in-
Table 1. Pore-water silica data from Hole 950A.

\begin{tabular}{|c|c|c|c|}
\hline $\begin{array}{l}\text { Core, section, } \\
\text { interval }(\mathrm{cm})\end{array}$ & $\begin{array}{c}\mathrm{Si} \\
(\mu \mathrm{M})\end{array}$ & $\begin{array}{l}\text { Core, section, } \\
\text { interval }(\mathrm{cm})\end{array}$ & $\begin{array}{c}\mathrm{Si} \\
(\mu \mathrm{M})\end{array}$ \\
\hline $1 \mathrm{H}-4,145-150$ & 400 & $16 \mathrm{H}-3,96-102$ & 148 \\
\hline $2 \mathrm{H}-4,145-150$ & 451 & $16 \mathrm{H}-4,145-150$ & 123 \\
\hline $3 \mathrm{H}-3,14-20$ & 164 & $16 \mathrm{H}-6,46-52$ & 136 \\
\hline $3 \mathrm{H}-4,65-70$ & 200 & $17 \mathrm{H}-2,53-60$ & 151 \\
\hline $3 \mathrm{H}-5,116-121$ & 352 & $17 \mathrm{H}-\mathrm{CC}, 4-10$ & 160 \\
\hline $3 \mathrm{H}-6,145-150$ & 433 & $18 \mathrm{X}-1,103-109$ & 179 \\
\hline $3 \mathrm{H}-7,32-38$ & 458 & $18 X-2,145-150$ & 209 \\
\hline $4 \mathrm{H}-1,25-30$ & 391 & $19 \mathrm{X}-1,42-48$ & 134 \\
\hline $4 \mathrm{H}-2,64-70$ & 636 & $19 \mathrm{X}-2,91-97$ & 136 \\
\hline $4 \mathrm{H}-3,133-139$ & 632 & $19 X-4,2-8$ & 173 \\
\hline $4 \mathrm{H}-5,42-48$ & 651 & $19 X-5,65-71$ & \\
\hline $4 \mathrm{H}-5,145-150$ & 606 & $20 \mathrm{X}-1,31-37$ & 89 \\
\hline $4 \mathrm{H}-6,89-92$ & 395 & $20 \mathrm{X}-2,89-95$ & 143 \\
\hline $5 \mathrm{H}-1,24-30$ & 388 & $20 \mathrm{X}-3,127-135$ & 106 \\
\hline $5 \mathrm{H}-2,49-56$ & 365 & $20 \mathrm{X}-4,140-150$ & 186 \\
\hline $5 \mathrm{H}-3,90-97$ & 422 & $20 X-6,21-27$ & 128 \\
\hline $5 \mathrm{H}-5,76-82$ & 441 & $21 \mathrm{X}-1,18-24$ & 120 \\
\hline $5 \mathrm{H}-5,145-150$ & 527 & $21 \mathrm{X}-2,85-91$ & 142 \\
\hline $5 \mathrm{H}-6,102-109$ & 499 & $21 \mathrm{X}-4,22-28$ & 121 \\
\hline $6 \mathrm{H}-1,16-21$ & 481 & $21 X-5,118-124$ & 94 \\
\hline $6 \mathrm{H}-2,70-76$ & 414 & $21 X-7,39-45$ & 138 \\
\hline $6 \mathrm{H}-4,13-19$ & 358 & $22 \mathrm{X}-1,42-48$ & 75 \\
\hline $6 \mathrm{H}-4,145-150$ & 305 & $22 \mathrm{X}-2,80-86$ & 125 \\
\hline $6 \mathrm{H}-5,96-102$ & 314 & $22 X-4,41-47$ & 119 \\
\hline $6 \mathrm{H}-6,5-11$ & 271 & $22 \mathrm{X}-4,140-150$ & 185 \\
\hline $7 \mathrm{H}-1,100-106$ & 244 & $22 X-6,118-124$ & 139 \\
\hline $7 \mathrm{H}-3,5-11$ & 228 & $23 \mathrm{X}-1,121-127$ & 72 \\
\hline $7 \mathrm{H}-3,145-150$ & 256 & $23 \mathrm{X}-3,28-34$ & 94 \\
\hline $7 \mathrm{H}-4,49-55$ & 237 & $23 \mathrm{X}-4,88-91$ & 83 \\
\hline $7 \mathrm{H}-5,100-106$ & 261 & $23 X-6,21-27$ & 162 \\
\hline $7 \mathrm{H}-7,3-9$ & 127 & $24 \mathrm{X}-1,52-58$ & 85 \\
\hline $8 \mathrm{H}-1,100-106$ & 243 & $24 \mathrm{X}-2,117-123$ & 79 \\
\hline $8 \mathrm{H}-3,10-16$ & 202 & $24 X-4,20-26$ & 97 \\
\hline $8 \mathrm{H}-4,70-76$ & 259 & $24 X-5,105-111$ & 104 \\
\hline $8 \mathrm{H}-5,145-150$ & 296 & $24 X-7,25-31$ & 139 \\
\hline $8 \mathrm{H}-7,52-59$ & 224 & $25 X-1,19-25$ & 73 \\
\hline $9 \mathrm{H}-2,50-56$ & 176 & $25 X-2,93-99$ & 100 \\
\hline $9 \mathrm{H}-3,100-106$ & 176 & $25 X-3,140-150$ & 236 \\
\hline $9 \mathrm{H}-4,145-150$ & 231 & $25 X-5,36-42$ & 66 \\
\hline $9 \mathrm{H}-5,50-56$ & 156 & $25 X-6,121-127$ & 148 \\
\hline $9 \mathrm{H}-7,44-50$ & 179 & $26 \mathrm{X}-1,22-28$ & 130 \\
\hline $10 \mathrm{H}-2,50-56$ & 172 & $26 \mathrm{X}-2,65-71$ & 58 \\
\hline $10 \mathrm{H}-4,145-150$ & 201 & $26 \mathrm{X}-3,94-100$ & 96 \\
\hline $10 \mathrm{H}-6,86-92$ & 153 & $26 X-5,9-15$ & 134 \\
\hline $10 \mathrm{H}-7,128-134$ & 157 & $26 \mathrm{X}-6,80-86$ & 130 \\
\hline $11 \mathrm{H}-1,25-31$ & 178 & $27 X-1,18-24$ & 67 \\
\hline $11 \mathrm{H}-2,83-89$ & 175 & $27 \mathrm{X}-2,114-120$ & 73 \\
\hline $11 \mathrm{H}-3,55-61$ & 143 & $27 \mathrm{X}-4,34-40$ & 123 \\
\hline $11 \mathrm{H}-4,77-83$ & 150 & $27 X-5,81-87$ & 92 \\
\hline $11 \mathrm{H}-5,66-72$ & 204 & $27 \mathrm{X}-5,145-150$ & 166 \\
\hline $11 \mathrm{H}-5,80-86$ & & $28 \mathrm{X}-1,32-40$ & 47 \\
\hline $11 \mathrm{H}-7,22-28$ & 195 & $28 \mathrm{X}-2,79-86$ & 43 \\
\hline $12 \mathrm{H}-1,98-104$ & 182 & $29 \mathrm{X}-1,27-33$ & 94 \\
\hline $12 \mathrm{H}-3,12-18$ & 203 & $29 X-2,71-77$ & 72 \\
\hline $12 \mathrm{H}-4,129-135$ & 197 & $29 \mathrm{X}-3,89-95$ & 103 \\
\hline $12 \mathrm{H}-4,145-150$ & 210 & $29 X-5,4-10$ & 62 \\
\hline $12 \mathrm{H}-6,110-116$ & 162 & $29 X-5,69-75$ & 53 \\
\hline $13 \mathrm{H}-1,48-54$ & 175 & $30 X-1,82-88$ & 177 \\
\hline $13 \mathrm{H}-3,36-42$ & 141 & $30 X-3,101-107$ & 206 \\
\hline $13 \mathrm{H}-4,142-148$ & 156 & $30 \mathrm{X}-4,140-150$ & 384 \\
\hline $14 \mathrm{H}-1,100-106$ & 162 & $30 X-5,49-55$ & 192 \\
\hline $14 \mathrm{H}-3,80-86$ & 164 & $30 X-6,102-108$ & 237 \\
\hline $14 \mathrm{H}-4,145-150$ & 145 & $31 \mathrm{X}-2,118-124$ & 454 \\
\hline $14 \mathrm{H}-6,51-57$ & 132 & $31 X-4,14-20$ & 317 \\
\hline $15 \mathrm{H}-1,90-96$ & 111 & $31 X-5,88-91$ & 190 \\
\hline $15 \mathrm{H}-3,30-36$ & 151 & $36 \mathrm{X}-1,140-150$ & 190 \\
\hline $15 \mathrm{H}-4,41-47$ & 84 & $36 \mathrm{X}-1,140-150$ & 186 \\
\hline $15 \mathrm{H}-5,96-102$ & 120 & $39 X-4,140-150$ & 279 \\
\hline $16 \mathrm{H}-2,56-62$ & 111 & & \\
\hline
\end{tabular}

terval near 290 mbsf seems to be the most promising for continued studies on the formation of authigenic silica phases. Because of the relatively low sample resolution in the latter interval, however, it may appear difficult to determine the exact depth location of such authigenic precipitate. In contrast, the high-resolution pore-water sampling for the sediments in the upper part of the two holes would allow the more precise detection of interval(s) with authigenic silica formation in the upper $100 \mathrm{mbsf}$.

The sample resolution of the routine shipboard pore-water samples, obviously, is insufficient to detect sites of precipitation in the sediments of the upper part of these holes. Distinct precipitation in- 
Table 2. Pore-water silica data from Hole 952A.

\begin{tabular}{|c|c|c|c|}
\hline $\begin{array}{l}\text { Core, section, } \\
\text { interval }(\mathrm{cm})\end{array}$ & $\begin{array}{c}\mathrm{Si} \\
(\mu \mathrm{M})\end{array}$ & $\begin{array}{l}\text { Core, section, } \\
\text { interval }(\mathrm{cm})\end{array}$ & $\begin{array}{c}\mathrm{Si} \\
(\mu \mathrm{M})\end{array}$ \\
\hline $1 \mathrm{H}-1,100-106$ & 252 & $15 \mathrm{H}-1,33-39$ & 127 \\
\hline $1 \mathrm{H}-3,48-54$ & 259 & $15 \mathrm{H}-2,97-103$ & 114 \\
\hline $1 \mathrm{H}-4,145-150$ & 434 & $15 \mathrm{H}-4,7-13$ & 138 \\
\hline $1 \mathrm{H}-5,5-11$ & 420 & $15 \mathrm{H}-5,91-97$ & 170 \\
\hline $1 \mathrm{H}-6,90-96$ & 548 & $15 \mathrm{H}-6,139-145$ & 139 \\
\hline $2 \mathrm{H}-3,10-16$ & 534 & $16 X-1,65-71$ & 117 \\
\hline $2 \mathrm{H}-4,60-66$ & 497 & $16 \mathrm{X}-2,126-132$ & 116 \\
\hline $2 \mathrm{H}-5,145-150$ & 434 & $16 \mathrm{X}-4,22-28$ & 142 \\
\hline $2 \mathrm{H}-6,40-46$ & 364 & $16 X-4,145-150$ & 164 \\
\hline $2 \mathrm{H}-7,130-136$ & 255 & $16 \mathrm{X}-5,114-120$ & 155 \\
\hline $3 \mathrm{H}-1,91-97$ & 348 & $17 X-1,44-50$ & 158 \\
\hline $3 \mathrm{H}-2,140-146$ & 304 & $17 \mathrm{X}-2,95-101$ & 174 \\
\hline $3 \mathrm{H}-4,50-56$ & 392 & $17 X-3,143-149$ & 164 \\
\hline $3 \mathrm{H}-4,145-150$ & 386 & $18 X-1,9-15$ & 141 \\
\hline $3 \mathrm{H}-6,10-16$ & 414 & $18 X-2,73-79$ & 197 \\
\hline $3 \mathrm{H}-7,30-36$ & 332 & $18 \mathrm{X}-4,22-28$ & 250 \\
\hline $4 \mathrm{H}-1,125-131$ & 563 & $18 X-4,140-150$ & 266 \\
\hline $4 \mathrm{H}-4,28-34$ & 690 & $18 X-5,104-110$ & 166 \\
\hline $4 \mathrm{H}-4,145-150$ & 665 & $18 X-6,133-139$ & 122 \\
\hline $4 \mathrm{H}-4,48-54$ & 576 & $19 X-1,26-32$ & 107 \\
\hline $5 \mathrm{H}-1,106-112$ & 483 & $19 \mathrm{X}-2,74-80$ & 134 \\
\hline $5 \mathrm{H}-4,92-98$ & 500 & $19 X-3,142-148$ & 160 \\
\hline $5 \mathrm{H}-4,145-150$ & 533 & $19 X-5,40-46$ & 133 \\
\hline $5 \mathrm{H}-6,99-105$ & 511 & $19 X-7,11-17$ & 129 \\
\hline $6 \mathrm{H}-1,91-97$ & 494 & $20 \mathrm{X}-1,93-99$ & 158 \\
\hline $6 \mathrm{H}-3,59-63$ & 404 & $20 \mathrm{X}-3,24-30$ & 149 \\
\hline $6 \mathrm{H}-4,145-150$ & 433 & $20 X-4,140-150$ & 195 \\
\hline $6 \mathrm{H}-5,60-66$ & 432 & $20 \mathrm{X}-5,22-28$ & 132 \\
\hline $6 \mathrm{H}-6,125-130$ & 354 & 20X-6, 88-94 & 114 \\
\hline $7 \mathrm{H}-1,85-91$ & 393 & $21 X-3,60-66$ & 118 \\
\hline $7 \mathrm{H}-3,23-29$ & 393 & $21 \mathrm{X}-4,95-101$ & 176 \\
\hline $7 \mathrm{H}-4,64-70$ & 409 & $21 X-5,19-25$ & 159 \\
\hline $7 \mathrm{H}-4,145-150$ & 380 & $21 X-6,128-134$ & 207 \\
\hline $7 \mathrm{H}-6,42-48$ & 344 & $22 \mathrm{X}-1,114-120$ & 143 \\
\hline $8 \mathrm{H}-1,80-86$ & 347 & $22 X-3,33-39$ & 134 \\
\hline $8 \mathrm{H}-3,23-29$ & 438 & $22 X-5,60-66$ & 157 \\
\hline $8 \mathrm{H}-4,110-116$ & 364 & $22 \mathrm{X}-6,114-120$ & 135 \\
\hline $8 \mathrm{H}-4,145-150$ & 392 & $23 X-1,90-96$ & 108 \\
\hline $8 \mathrm{H}-6,37-43$ & 344 & $23 X-3,81-87$ & 148 \\
\hline $9 \mathrm{H}-1,67-73$ & 318 & $23 X-4,132-138$ & 88 \\
\hline $9 \mathrm{H}-2,138-144$ & 306 & $23 \mathrm{X}-4,140-150$ & 152 \\
\hline $9 \mathrm{H}-4,84-90$ & 194 & $23 \mathrm{X}-6,88-94$ & 139 \\
\hline $9 \mathrm{H}-4,145-150$ & 278 & $24 \mathrm{X}-1,23-29$ & 121 \\
\hline $9 \mathrm{H}-5,135-141$ & 219 & $24 \mathrm{X}-2,121-127$ & 87 \\
\hline $10 \mathrm{H}-1,88-94$ & 160 & $24 X-4,46-52$ & 140 \\
\hline $10 \mathrm{H}-3,7-13$ & 186 & $24 X-5,92-98$ & 93 \\
\hline $10 \mathrm{H}-4,68-74$ & 123 & $25 \mathrm{X}-1,22-28$ & 110 \\
\hline $10 \mathrm{H}-4,145-150$ & 227 & $25 X-2,86-92$ & 132 \\
\hline $10 \mathrm{H}-5,109-115$ & 201 & $25 X-4,42-48$ & 156 \\
\hline $10 \mathrm{H}-6,139-145$ & 221 & $25 \mathrm{X}-5,95-101$ & 128 \\
\hline $11 \mathrm{H}-2,36-42$ & 224 & $26 \mathrm{X}-1,84-90$ & 196 \\
\hline $11 \mathrm{H}-4,10-16$ & 187 & $26 \mathrm{X}-2,140-146$ & 71 \\
\hline $11 \mathrm{H}-5,80-86$ & 214 & $27 X-1,34-40$ & 187 \\
\hline $11 \mathrm{H}-6,137-143$ & 217 & $27 \mathrm{X}-2,121-127$ & 122 \\
\hline $12 \mathrm{H}-1,41-47$ & 209 & $27 \mathrm{X}-4,31-37$ & 169 \\
\hline $12 \mathrm{H}-2,112-118$ & 239 & $27 X-4,140-150$ & 203 \\
\hline $12 \mathrm{H}-4,25-31$ & 223 & $27 X-5,108-114$ & 174 \\
\hline $12 \mathrm{H}-4,145-150$ & 253 & $28 \mathrm{X}-1,42-50$ & 114 \\
\hline $12 \mathrm{H}-5,83-89$ & 210 & $28 \mathrm{X}-2,97-103$ & 129 \\
\hline $12 \mathrm{H}-6,143-149$ & 149 & $28 \mathrm{X}-3,107-112$ & 182 \\
\hline $13 \mathrm{H}-2,71-77$ & 183 & $29 X-2,85-91$ & 169 \\
\hline $13 \mathrm{H}-3,138-144$ & 142 & $29 X-3,25-31$ & 139 \\
\hline $13 \mathrm{H}-5,56-62$ & 143 & $29 X-4,113-119$ & 148 \\
\hline $13 \mathrm{H}-6,132-138$ & 122 & $30 X-4,140-150$ & 430 \\
\hline $14 \mathrm{H}-2,70-76$ & 94 & $33 \mathrm{X}-4,140-150$ & 1056 \\
\hline $14 \mathrm{H}-4,5-11$ & 134 & $37 X-4,140-150$ & 1119 \\
\hline $14 \mathrm{H}-4,145-150$ & 190 & $39 X-4,140-150$ & 944 \\
\hline $14 \mathrm{H}-5,116-122$ & 102 & $45 X-4,140-150$ & 860 \\
\hline
\end{tabular}

tervals can, however, be elucidated using the high-resolution sampling data.

\section{CONCLUSIONS}

Silica pore-water concentrations in the top 50 mbsf faithfully record the presence of biogenic silica in organic-rich turbidites. Between 50 and $250 \mathrm{mbsf}$, that is, between 1 and $10 \mathrm{Ma}$, the silica porewater concentration is low and stable, pointing to the absence of biogenic silica in the organic-rich turbidites. Such an absence could in-
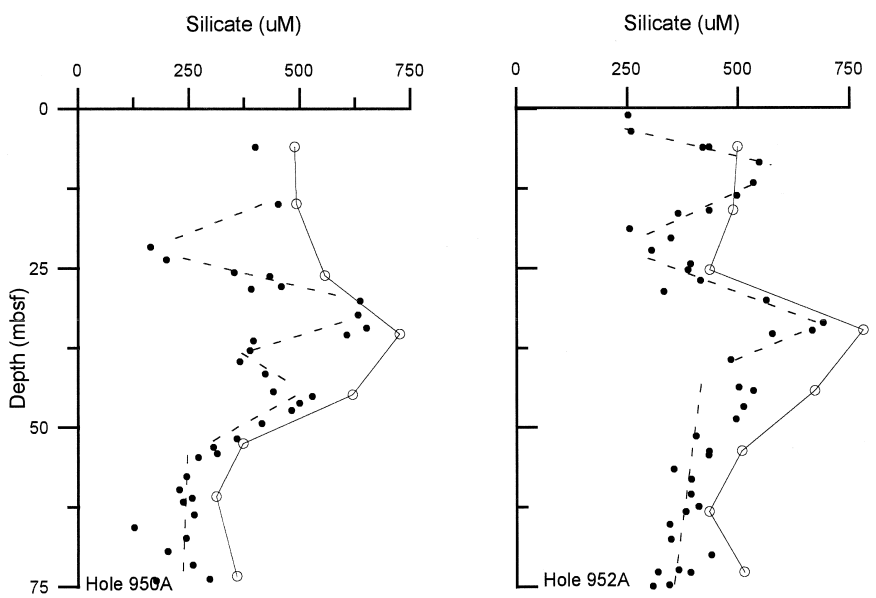

Figure 2. Silica pore-water concentration vs. depth for the interval of 0-75 mbsf at Holes 950A and 952A. Open circles = routine samples analyzed aboard ship; solid circles $=$ high-resolution samples analyzed at Utrecht University immediately after the cruise.

dicate a change in source area, or in the northwest African upwelling system during that period.

About 280 mbsf in Hole 950A and below 290 mbsf in Hole 952A, enhanced levels of silica are observed in the pore waters, which indicates that biogenic silica is present again in the organic-rich turbidites. The high-resolution pore-water sampling in Holes 950A and 952A has resulted in the detection of potential intervals in which authigenic silica phases must have formed.

\section{ACKNOWLEDGMENTS}

The major effort done on board the JOIDES Resolution during Leg 157 by the chemlab team in particular, is acknowledged. Anne Pimmel, Martine Gerard, Ian Jarvis, and Robert Kemp, besides their usual duties, have faithfully processed endless numbers of additional mud samples and squeezers for this study. Ivar Nijenhuis is thanked for transporting the samples rapidly and cool to Utrecht University. Helen de Waard and Gijs Nobbe are acknowledged for analytical support. J. Thomson and P. Weaver are acknowledged for their constructive review. This is contribution 96.1202 of NSG. This research was supported by GOA/NWO Grant 750.195.16.

\section{REFERENCES}

De Lange, G.J., 1986. Early diagenetic reactions in interbedded pelagic and turbidic sediments in the Nares Abyssal Plain (western North Atlantic): consequences for the composition of sediment and interstitial water. Geochim. Cosmochim. Acta, 50:2543-2561.

De Lange, G.J., Cranston, R.E., Hydes, D.H., and Boust, D., 1992. Extraction of pore water from marine sediments: a review of possible artifacts with pertinent examples from the North Atlantic. Mar. Geol. 109:53-76.

De Lange, G.J., Jarvis, I., and Kuijpers, A., 1987. Geochemical characteristics and provenance of late Quaternary sediments from the Madeira Abyssal Plain, North Atlantic. In Weaver, P.P.E., and Thomson, J. (Eds.), Geology and Geochemistry of Abyssal Plains. Geol. Soc. Spec. Publ. London, 31:147-165.

De Lange, G.J., and Rispens, F.B., 1986. Indication of a diagenetically induced precipitate of an Fe-Si mineral in sediment from the Nares Abyssal Plain, western North Atlantic. Mar. Geol., 73:85-97.

Fanning, K.A., and Pilson, M.E.Q., 1971. Interstitial silica and pH in marine sediments: some effects of sampling procedure. Science, 173:1228-1231.

Harder, H., 1978. Synthesis of iron layer silicate minerals under natural conditions. Clays Clay Miner., 26:65-72. 
Hein, J.R., Yeh, H.-W., and Alexander, E., 1979. Origin of iron-rich montmorillonnite from the manganese nodule belt of the north equatorial pacific. Clays Clay Miner., 27:185-194.

Hurd, D.C., 1973. Interactions of biogenic opal, sediment and seawater in the central equatorial Pacific. Geochim. Cosmochim. Acta, 37:2257-2282.

Jahnke, R., Heggie, D., Emerson, S., and Grundmaris, V., 1982. Pore water of the central Pacific Ocean: nutrient results. Earth Planet. Sci. Lett., 61:233-256.

Kuijpers, A., 1982. Sediment studies in the western Madeira Abyssal Plain. In Geological Studies on Abyssal Plains in the North Atlantic. Rijks Geol. Dienst Progr. Rep.,1982:41-107.

Mangelsdorf, P.C., Jr., Wilson, T.R.S., and Daniell, E., 1969. Potassium enrichments in interstitial waters of recent marine sediments. Science, 165:171-174.

Maris, C.R.P., and Bender, M.L., 1982. Upwelling of hydrothermal solutions through ridge flank sediments shown by pore water profiles. Science, 216:623-626.

Sayles, F.L., Mangelsdorf, P.C., Wilson, T.R.S., and Hume, D.N., 1976. A sampler for the in situ collection of marine sedimentary pore waters. Deep-Sea Res. Part A, 23:259-264.

Sayles, F.L., Manheim, F.T., and Waterman, L.S., 1973. Interstitial water studies on small core samples, Leg 15. In Heezen, B.C., MacGregor, I.D., et al., Init. Repts. DSDP, 20: Washington (U.S. Govt. Printing Office), 783-804.

Schink, D.R., Fanning, K.A., and Pilson, M.E.Q., 1974. Dissolved silica in upper pore waters of the Atlantic Ocean floor. J. Geophys. Res., 79:2243-2250.

Schmincke, H.-U., Weaver, P.P.E., Firth, J.V., et al., 1995. Proc. ODP, Init. Repts., 157: College Station, TX (Ocean Drilling Program).

Weaver, P.P.E., and Kuijpers, A., 1983. Climatic control of turbidite deposition on the Madeira Abyssal Plain. Nature, 306:360-363.

Weaver, P.P.E., and Rothwell, R.G., 1987. Sedimentation on the Madeira Abyssal Plain over the last 300,000 years. In Weaver, P.P.E., and Thomson, J. (Eds.), Geology and Geochemistry of Abyssal Plains. Geol. Soc. Spec. Publ. London, 31:71-86.

Weaver, P.P.E., Rothwell, R.G., Ebbing, J., Gunn, D., and Hunter, P.M., 1992. Correlation, frequency of emplacement and source directions of megaturbidites on the Madeira Abyssal Plain. Mar. Geol., 109:1-20.

Date of initial receipt: 3 July 1996

Date of acceptance: 17 January 1997

Ms 157SR-142 